12. Stratégia digitálnej transformácie Slovenska 2030. URL: https://www.mirri.gov. sk/wp-content/uploads/2019/06/Strategia-digitalnej-transformacie-Slovenska-2030.pdf

13. Akčný plán digitálnej transformácie Slovenska na roky 2019-2022. URL: https://www.mirri.gov.sk/wp-content/uploads/2019/07/Akcny-plan-DTS_2019-2022. pdf

Матеріал надійшов до редакиіï 11.01.2021 p.

УДК 324:32.019.51:323.25

\title{
Сергій Федонюк,
}

кандидат географічних наук,

доцент кафедри міжнародних комунікацій та політичного аналізу,

Волинський національний університет імені Лесі Українки,

sergii.fedoniuk@vnu.edu.ua

ORCID ID 0000-0003-2853-8905

Анастасія Ткачук,

магістр спеціальності 291 «Міжнародні відносини,

суспільні комунікації та регіональні студії»,

Волинський національний університет імені Лесі Українки

DOI 10.29038/2524-2679-2021-01-174-188

\section{КОМУНІКАТИВНИМ СКЛАДНИК СУЧАСНИХ ПРОТЕСТІВ}

У иүій статті встановлено особливості комунікації сучасних протестних рухів в аспекті масового співробітництва.

Зокрема, показано, щуо сучасні соціальні й політичні протести розвиваються на основі масової комунікації між потенційними учасниками, які не спираються на оформлені організаційні структури, протест $\epsilon$ самовідтворюваним прочесом, що трунтується на сугестії алармізму засобами масової комунікації. У зв'язку з ичим високу ефективність як рушійний фактор масових протестів мають відігравати соціальні мережі, спроможні швидко поширювати такі парламістські настрої серед їхніх учасників. Великі масові демонстрації останнього десятиліття організовані шляхом мобілізації через соиіальні мережі, а потім показали свою силу масовою присутністю людей на

(C) Федонюк C., Ткачук A., 2021 
вулиці. Протестні настрої сприяють розвитку соціальних мереж із їхніми спільнотами. Установлено, щзо основну роль у цзьому процесі відіграє комунікація протесту, яка, по суті, є комунікацією відкритого (масового) співробітництва. Вона формується на основі індивідуальних інформаційних контактів між суб'єктами, котрі реалізують їх у середовищі соціальних мереж. Така комунікація має інтерактивний характер $і$ розвивається завдяки залученню інформаційних ресурсів із мережі. Для неї характерна відсутність системно-структурной організації й об 'єктна орієнтація. Друга характерна риса - конвергениія засобів та учасників комунікації. Більше значення має не наявність спеціалізованих і кваліфікованих комунікаторів зі сфери традиційних засобів масової інформацї, а залучення великой кількості інформаційних прос'юмерів (професійних споживачів інформаціï), тобто активних генераторів контенту з представників аудиторії. Комунікаційні процеси в соціальних мережах розвиваються як низка подій, у якій кожна наступна подія залежить від попередньої. Зазвичай, такий підхід не спроможний створити послідовність, у якій би спостерігалася якась тенденція, і для досягнення планованого результату потребує утворення фокусів впливу. У практиці протестної комунікації таке фокусування здійснюється за допомогою підключення традиційних (інституційних) 3МІ. Результатом взаємодії інтерактивної комунікації й офлайну $\epsilon$ внесення консолідаційного чинника, який має все більше гуртувати однодумців проти табору опонентів. Зазначені особливості протестної комунікації проявляються в ефективній взаємодії соціальних мереж із сектором традииійних ЗМI.

Ці властивості характеризують протест, щзо розвивається на основі інтерактивної комунікації, відкриту систему, орієнтовану на взаємодію з оточеннями не на внутрішні ресурси, щьо властиво для масового співробітництва.

Ключові слова: комунікація, протест, соціальні мережі.

\section{1. ВСТУП}

Постановка проблеми. Протягом лише останнього десятиліття відбулися масштабні протести в різних регіонах світу. Серед найзначніших - події «Арабської весни» (2010-2011рр.) та української Революції гідності (2013-2014 рр.). Із серпня 2020 р. розгорнулися масштабні протести в Білорусі. Зазвичай такі протести або від початку мали політичну мотивацію, або набували ї в процесі розгортання й призводили до революційних перетворень у внутрішній і зовнішній політиці країн. 
Інтенсивне використання інтернету та особливо соціальних медіа було загальним знаменником у популярних демонстраціях, які відбувались останні кілька років за різних сценаріїв. Соціальні рухи зазнали впливу чинників, пов'язаних із сучасними технологіями масової комунікації, особливо в аспекті їх організації та розгортання.

Популярність сайтів соціальних мереж (ССМ) значною мірою сприяла поширенню соціальних демонстрацій [1]. Переломним рубежем у консолідації населення в середовищі ССМ стали 2010-2011 рр. У таких регіонах, як Близький Схід і Північна Африка, Латинська Америка, Європа, у 2011 р. користувачі інтернету проводили в ССМ близько чверті всього часу користування інтернетом, що на 35 \% більше, порівняно 32010 p. [2]. Більше того, YouTube став найпопулярнішою онлайн-відеоплатформою, пропонуючи два з п'яти переглянутих відео в усьому світі [1]. Активне включення ССМ у комунікацію протесту розпочалося з їх поширенням назагал, починаючи від кінця 2000-х рр. Суттєве значення в цьому аспекті мали технології масового мобільного доступу до інтернету.

Щодо соціальних рухів, то великі масові демонстрації останнього десятиліття були організовані шляхом мобілізації через соціальні мережі, а потім показали свою силу масовою присутністю людей на вулиці [3]. Вони були об'єднані навколо закликів до змін, таких як «Арабська весна», яка розпочалася наприкінці 2010 р., рух «Індігнадас» в Іспанії у 2011 р., акції протесту в Бразилії у 2013 р., українська Революція гідності 20132014 р., Революція парасольок у Гонконзі 2014 р. та ін. Ці рухи переважно складалися 3 молодих людей, закликаних до дії через соціальні мережі; і в усіх цих випадках не було посередництва в мобілізації за класичною лінією, а саме: політичних партій, профспілок та домінування звичайних каналів комунікації $[4 ; 5 ; 6]$.

Соціальні рухи, опосередковані інтернетом, не мають лідерів або ієрархії, відображаючи горизонтальний принцип організації інтернету й недовіру як до сформованих лідерів, так і до криз представництва [3].

Аналіз останніх досліджень і публікацій. Із предмету цього дослідження в наукових журналах 3 інформаційно-комунікаційних технологій знайдено огляд літератури з питань інформації, комунікації та суспільства в аспекті предмету цього дослідження, підготовлений Гарретом [7]. Натомість у результаті огляду основних журналів у сферах соціології, комунікації, маркетингу, політики відзначимо аналіз Вебстера й Ватсона [8]. За такими ключовими словами, як соціальні медіа, соціальний протест, повстання, мережева політика, мережеві 
соціальні рухи, знайдено декілька десятків публікацій, які можна систематизувати за змістом. Деякі статті стосуються структурних факторів, пов'язаних із використанням комунікації соціальних медіа в соціальних рухах, тобто контекстуальних умов кожної країни, у якій відбувалися масові протестні рухи. Інші статті стосуються факторів, пов'язаних із використанням комунікації соціальних медіа в соціальних рухах, а саме факторів, що вважаються найближчими до самих рухів, будучи їх специфічними модеруючими факторами, які можуть допомогти виявити еволюцію та динаміку опосередкованих соціальних рухів у соціальних мережах.

Терміни «мережева політика» 1 «мережеві соціальні рухи» стали поширеними під час вивчення політичних протестів і колективних дій у цифрову епоху (Беннет та Сегерберг, 2013 [9], Кастельс, 2012 [10], Ерл і Кімпорт, 2011 [11], Фаріс, 2013 [12]). До сьогодні теоретична база дослідження цих явищ перебуває на стадії формування, а опубліковані результати часто покладаються на неявні припущення про те, як функціонують соціальні мережі й не завжди узгоджуються з усталеними висновками в галузі мережевих наук (Іслі й Кляйнберг, 2010 [13], Ньюман, 2010 [14]) та аналізу соціальних мереж (Вассерман і Фауст, 1994 [15], Керінгтон та ін., 2005 [16], Кадушин, 2012 [14], Ерл і Кімпорт, 2011 [11], Фаріс, 2013 [12]). Тому вважаємо, що існує потреба для доповнення базових знань про протестну комунікацію й мережні рухи, які стали основою соціально-політичних потрясінь нашого часу, для кращого розуміння їхньої природи та тенденцій розвитку. Недавні політичні події - від арабської весни чи руху «Окупуй» 2011 р. до останніх акцій протесту, що відбулися в Туреччині, Бразилії, Україні й Гонконгу (2013-2014) і Білорусі (2020), викликали великий інтерес до того, як сучасна комунікація допомагає координувати велику кількість людей за відсутності центральних організацій.

Мета статті - визначити особливості комунікаційних чинників сучасних соціальних і політичних протестів, що розвиваються на основі інтерактивної масової комунікації, виходячи з припущення про те, що в їх основу покладено масове співробітництво як концептуальну основу процесів соціальної взаємодії в умовах вільного обміну інформацією в інтернеті.

Методичні основи дослідження. Для досягнення мети цього дослідження використано описовий, аналітичний підхід, який переважно спирається на аналіз джерел, порівняльну експертизу досліджень, що стосуються масової комунікації, комунікації в соціальних мережах, 
організації взаємодії соціальних мереж та пов'язаних із цим проблем. Застосовано якісний підхід із метою вивчення явища, якому бракує уваги в наявній літературі з погляду взаємозв'язку масової співпраці та протестної комунікації.

\section{2. РЕЗУЛЬТАТИ ДОСЛІДЖЕННЯ}

Протестом є відносно відкрита реакція на суспільну ситуацію, зазвичай, спрямована проти неї. Протестувальники можуть організувати протест як спосіб публічного оприлюднення своїх думок, намагаючись вплинути на громадську думку чи урядову політику або навіть ужити прямих дій, намагаючись здійснити бажані зміни самостійно. Але протестна діяльність $\epsilon$ прямим актом відкидання інститутів, часто має емоційний характер, що призводить до відсутності чітких вимог і пропозицій, інколи адресована іншим опозиційним групам, у тому числі елітам, також нерідко може супроводжуватися різними формами насильства (Терроу [18]).

За відсутності протесту соціально-політичні системи, представлені, зазвичай, владою й позицією, успішно функціонують і забезпечують політичний діалог у взаємозв'язку із запитами суспільства. Натомість надмірна актуалізація та наголошення на соціальних проблемах призводять до перевищення певного порогу їх сприйняття, коли вони починають сприйматися як нестерпні, тобто критична маса людей незадоволена структурами суспільства, а кількість опонентів певних структур зростає до такої міри, що це невдоволення й воля до змін починають сприйматися як належне. Така критична фаза не є необхідним результатом поглиблення соціального антагонізму (скажімо, зростання бідності, безробіття, погіршення екології), але $\epsilon$ результатом перцепції й усвідомлення поглиблення деякого антагонізму (Х. Фукс [19]).

Із посиленням такої протестної комунікації зростає гострота розуміння суспільних, економічних, екологічних чи інших ризиків і досить звичні для певного суспільства негативні явища, як-от: корупція, бідність, соціальна нерівність, починають інтерпретуватися як ненормальні та небезпечні. А це призводить до все більшого обговорення цих самих проблем, тобто йдеться про самовідтворювальну функцію протестної комунікації на основі страху й тривоги (Луман [20]). Страх і тривога, викликані обговоренням соціальних чи екологічних криз, спричиняють загострення комунікації цих небезпек i, отже, запуск нових циклів їх комунікативної трансляції.

У зв'язку із всепроникністю масової соціальної комунікації нинішні протести актуалізуються у формі кампаній, що провокуються 
якимись подіями-тригерами, наприклад оприлюдненням шокуючого контенту (самоспалення Мухаммеда Буазізі в Тунісі як провокуючий чинник «Арабської весни») чи уявно небажаної для потенційної протестної аудиторії інформації (заява голови уряду Миколи Азарова про призупинення процесу підготовки до підписання Угоди про асоціацію між Україною та ЄС як привід Революції гідності). Через тотальну проникність засобів масової комунікації і їх інтерактивних характер, де кожен учасник $\epsilon$ проактивним комунікатором, одиничний тригер може актуалізувати весь комплекс протестної реакції - від швидкого поширення протестних меседжів у соціальних мережах до масових виступів.

Що стосується логіки комунікації протесту, то, незважаючи на наявність програмних цілей у протестантів, протест не пропонує альтернативних рішень i $\epsilon$ «альтернативою без альтернативи», а самоздійснення протесту генерує його власну проблему, яку він покликаний розв’язати [21]. Так, усвідомлення факту гноблення та його комунікативне обговорення як специфічної протестної теми учасниками протесту перетворює те, що раніше вважалося нормальним, у ненормальне й вимагає усунення. Цю тезу можна проілюструвати на прикладі радикальної зміни сприйняття президента Білорусі О. Лукашенка лише протягом кількох місяців 2020 р. - від «батька» до «гнобителя».

Основою сучасних протестів $є$ масова комунікація на основі інтерактивних каналів i телебачення. Проте організаційно-ділова й технологічна специфіка телебачення зумовлює його адміністративну концентрацію, а отже, потенційну контрольованість із боку влади. Тому основою масштабних протестів і революцій останнього десятиліття стала інтерактивна комунікація - така, що забезпечує інтерактивний характер спілкування й проактивну позицію окремих індивідів, що репрезентують цільову аудиторію.

На цьому тлі виділяється зворотний спосіб масового інформування представлений соціальними мережами. У різних формах своєї організації та різними способами донесення інформації до аудиторії соціальні мережі формують інформаційні потоки від низу до верху й у сторони, уключаючи зворотний зв'язок для традиційних засобів масової інформації. А завдяки присутності традиційних 3MI в інтернеті, саме їх зв'язки із новими медіа утворює матеріальну базу комунікації протесту.

Принциповою характеристикою інтерактивної комунікації на базі соціальних мереж є свобода обміну інформацією, тобто ресурсами. А це - ознака форми суспільної організації, яку визначають як масове співробітництво [22]. Головною ознакою масового (відкритого) співробітництва є принципова орієнтація не на внутрішньоорганізаційні 
ресурси й контакти, а на взаємодію з мережею. За такого підходу змінюється сама суть організації - вона втрачає сенс стосовно якогось формально наявного суб'єкта та формується «назовні», не будучи підпорядкованою жодному формальному впливу й розвивається стохастично.

У такому аспекті протестна комунікація, по суті, є варіантом спіралі знань (протестних тем). А відсутність формальних і процедурних правил й обмежень $є$ запорукою значно швидшого, порівняно з моделями на основі традиційних засобів комунікації, обороту цих знань. Із такого погляду, виділимо дві особливості інтерактивної протестної комунікації.

По-перше, це іiі об'єктна орієнтація, тобто відсутність системноструктурного підходу в організації - інтерактивна комунікація протесту не спирається на формальні й ієрархічні структури й часто може не мати організаційних центрів. Незважаючи на таку несистемність i неінстигуційність, комунікація протесту, утім, у сумі призводить до консолідації значних мас протестувальників. Об'єктно-орієнтований підхід у розумінні комунікації протесту пов'язаний із виділенням об'єктів (а не процесів), коли статична структура системи описується в термінах об'єктів і зв'язків між ними, а поведінка - у термінах обміну повідомленнями між об'єктами. По суті, протестна комунікація в розподілених інтерактивних мережах формується навколо відособлених тем за участі незалежних комунікаторів, що загалом пояснює успіх неінституціолізованих протестів і революцій сучасності.

Крім того, комунікаційним процесам у соціальних мережах притаманна властивість Маркова [23], тобто в будь-який момент часу умовний розподіл майбутніх станів процесу із заданими поточним і минулими станами залежить тільки від поточного стану, але не від минулих станів (властивість відсутності пам'яті), що притаманно сукупностям великих чисел, - а такі ознаки й мають соціальні мережі в інтернеті. А послідовність подій у соціальній мережі моделюється як ланцюг Маркова - нитка подій, у якій кожна наступна подія залежить від попередньої. Зазвичай, такий підхід не здатний створити послідовність, у якій би спостерігалася якась тенденція, але ця властивість є суттєвою щодо формування впливу в соціальних мережах [24].

Марківська властивість проявляється в тому, як набувають популярності інтернет-сторінки, особливо в середовищі ССМ, - показником ранжування стає індукований стаціонарний розподіл сторінки в усталеному стані посилаються інші часто відвідувані сторінки, а отже, більш відвідувані стають найбільш релевантними [25]. 
Щодо адміністрування це слабоструктурована система проєктного управління, яка для досягнення планованого результату потребує утворення фокусів впливу. На практиці таке фокусування здійснюється за допомогою підключення традиційних (інституційних) 3МІ. У перші роки після появи феномену протестних соціальних комунікацій в інтернеті стверджувалося, що в них є досить мала участь 3МI (Каммартс та ін., 2013, с. 3 [26]). Проте сьогодні гака участь - важлива умова переростання локальних протестів у глобальні. Інтернет та офлайн почали все тісніше взаємодіяти, однак досі проведено мінімум досліджень цього явища. Можемо врахувати «ланцюг еквівалентності» (Лакло і Муф, 1985 [27]) в протестних рухах, концепція якого полягає в необхідності внесення консолідуючого чинника, який має все більше гуртувати однодумців проти табору опонентів. А для цього, як стверджується в зазначеному дослідженні, важливо ідентифікувати спільного супротивника (ворога) для різних ланцюгів еквівалентності.

Окремі автори також обгрунтовують як базу для формування таких ланцюгів логіку самомедіації (Каммарст, 2014 [28]). Самомедіація сприяє посиленню колективних дій і будує зв'язки, поширення повідомлень стає набагато швидшим, а канали комунікації між активістами покращуються. Установлені таким способом зв'язки більш специфічні й міцні, якщо формуються на почутті близькості та довіри. Це проявлялося, наприклад, у процесі «живої» комунікації блогерів і стрімерів під час гуртування на Майдані Незалежності в період Революції гідності.

Зазначені особливості протестної комунікації проявилися в ефективній взаємодії соціальних мереж із сектором традиційних ЗМІ, насамперед телебаченням та інтернет-телебаченням, і розвитку гібридних моделей масової комунікації, таких як блогінг і стримінг, що чітко проявилося під час Революції гідності в Україні у 2013-2014 рр. [29].

Фактично маємо місце поєднання типової для масового співробітництва відкритої моделі «безструктурної» комунікації соціальних мереж зі структурованою комунікацією інституційних 3MI, тобто виникає новий «гібридний» тип комунікації, який потребує окремого глибшого дослідження.

Другою особливістю інтерактивної протестної комунікації $\epsilon$ конвергенція засобів і методів розв'язання проблеми (мети комунікації протесту). Якщо в інституціолізованій системній комунікації події висвітлювали професійні журналісти, часто спеціалізовані, то інтерактивна несистемна комунікація грунтується на масовому включенні в процес нефахових інформаційних «прос'юмерів» (professional consumer). Володін- 
ня інструментами популяризації та просування контенту в соціальній мережі й підключений до мережі портативний термінал (смартфон, лептон тощо) плюс особиста мобільність дають змогу генерувати актуальний контент особою, яка не обов'язково має спеціальну фахову підготовку. Конвергенція стосується як засобів комунікації, так і компетентностей iii учасників. Відтак у якості комуніканта, котрий повідомляє про події протесту для масової аудиторії, може виступати будь-яка особа, розміщуючи повідомлення на своїй сторінці в соціальній мережі.

Мережева організація, заснована на масовому співробітництві, забезпечує також виконання чи не найголовнішої умови успіху протестів - залучення ресурсів. Це, передусім, людські ресурси учасників соціальних взаємодій, що формуються навколо провідних тем протестів, а також краудфандинг. Соціальні рухи, засновані на соціальних медіа, є піринговими. У формуванні такої мережі ключову роль відіграють процеси Р2Р, що виникають унаслідок високого ступеня зв'язку соціальних медіа в режимі реального часу.

Розглянуті особливості комунікації загалом були властиві протестам, у яких суттєву роль відігравали мережеві технології спілкування й передавання інформації. Проте з часом унаслідок розвитку програмної й апаратної бази самі ці технології й заснована на них організація комунікації зазнавали змін, що проявилося, наприклад, у розглянутому вище «зрощенні» ССМ із мережевим телебаченням (Україна, 20132014) або в широкому використанні мобільних застосунків для обміну контентом і каналів на їх основі з переважно одновекторним передаванням повідомлень (Білорусь, 2020 р.) [30]. I хоча суті протестної комунікації це не змінює, така еволюція може бути предметом окремого дослідження.

\section{3. ВИСНОВКИ ТА ПЕРСПЕКТИВИ ПОДАЛЬШИХ ДОСЛІДЖЕНЬ}

У підсумку можемо відзначити, що сучасні протести розвиваються на базі інтерактивної об'єктно-орієнтованої й конвергентної комунікації, на організаційно-технологічній базі сайтів соціальних мереж, яка часто функціонує у взаємодії з традиційними каналами масової інформації (передусім телебаченням). Об'єктно-орієнтована сутність інтерактивної несистемної комунікації протесту призводить до того, що вона розвивається відповідно до закономірностей ланцюгів еквівалентності в розподілених інтерактивних мережах, де фокусування відбувається навколо відособлених тем за участі незалежних комунікаторів. Проте 
це призводить до консолідації значних мас протестувальників. Для комунікації протесту властива конвергенція засобів і методів досягнення iї мети. Ця конвергенція стосується як засобів комунікації, так i компетентностей іiі учасників, що проявляється в масовому включенні в процес несистемних і формально нефахових представників аудиторії масової комунікації, які водночас виступають як неінституційні генератори й поширювачі контенту.

Комунікаційні процеси в соціальних мережах розвиваються як низка подій, у якій кожна наступна подія залежить від попередньої. Зазвичай, підхід не здатний створити послідовність, у якій би спостерігалася тенденція й для досягнення планованого результату, потребує утворення фокусів впливу. У практиці протестної комунікації таке фокусування здійснюється за допомогою підключення традиційних (інституційних) 3МІ. Результатом взаємодії інтерактивної комунікації й офлайну $\epsilon$ внесення консолідуючого чинника, який має все більше гуртувати однодумців проти табору опонентів. Зазначені особливості протестної комунікації проявляються в ефективній взаємодії соціальних мереж із сектором традиційних ЗМІ.

Ці властивості характеризують протест, що розвивається на основі інтерактивної комунікації як відкриту систему, орієнтовану на взаємодію 3 оточенням, а не на внутрішні ресурси, що властиво для масового співробітництва.

Наступним етапом у контексті предмету i результатів цього дослідження логічно розглянути еволюцію інтерактивної комунікації протесту залежно від розвитку технологій і моделей сучасної масової комунікації, зокрема становлення нових гібридних форм комунікації та ще глибшої конвергенції з розмиттям меж між секторами традиційних і мас-колаборативних соціальних каналів.

\section{СПИСОК ВИКОРИСТАНИХ ДЖЕРЕЛ}

1. Mansour, E (2012). The role of social networking sites (SNSs) in the January 25th revolution in Egypt. Libr. Rev, 61(2), pp. 128-159.

2. ComScore: ComScore video metrix (2011). URL: http://www.comscore.com/por/. 10 March 2015.

3. Castells, Manuel (2013). Redes de indignagdo e espercmga: movimentos sociaisjicu na era da internet. Tradução Carlos Alberto Medeiros. Rio de Janeiro: Zahar, 271 p.

4. Peruzzo, C. (2013). Movimentos sociais, redes virtuais e midia alternativa no junho em que «o gigante acordou». MATRIZes, 7 (2), pp. 73-93.

5. Haryey, D., Maricato, E., Zizek, S., Davis, M., Maior, J. F, Iasi, M., e de Oliveira, P. R. (2013). Cidades rebeldes: Passe livre e as manifestaçoes que lomaram as ruas do Brasil. Boitempo Editorial. 
6. Ramos, A., Oliveira, R. (2014). Indivíduos, sociedade, tecnologia: as manifestaçoes nas ruas das cidades brasileiras e as redes sociais. Revista Tecnologia e Sociedade, 10 (20), 2014.

7. Garrett, R. K. (2006). Protest in an information society. Inf. Commun. Soc, 9, pp. $202-224$.

8. Webster, J., Watson, R. T. (2002). Analyzing the past to prepare for the future: writing a literature review. MIS Q, 26 (2), pp. xiii-xxiii.

9. Bennett, W. L., \& Segerberg, A. (2013). Tbe logic of connective action: Digital media and the personalization of contentious politics. New York, NY: Cambridge University Press.

10. Castells, M. (2012). Networks of Outrage and Hope, Social Movements in the Internet Age. Polity, Cambridge.

11. Earl, J., \& Kimport, K. (2011). Digitally enabled social change: Activism in the Internet age. Cambridge, MA: MIT Press.

12. Faris, D. (2013). Dissent and Revolution in a Digital Age: Social Media Blogging, and Activism in Egypt. I. B. Tauris, London.

13. Easley, D., Kleinberg J. (2010). Networks, Crowds, and Markets: Reasoning About a Highly Connected World. Cambridge University Press, New York.

14. Newman M. E. J. (2010). Networks. An Introduction. Qxford University Press, Oxford.

15. Wasserman, S., Faust, K. (1994). Social Network Analysis: Methods and Applications, Cambridge: University Press.

16. Carrington, P. J., Scott, J., Wasserman, S. (2005). Models and Methods in Social Network Analysis. Cambridge University Press, Cambridge.

17. Kadushin, C. (2012). Understanding Social Networks. Theories, Concepts and Findings. Oxford University Press, Oxford.

18. Tarrow, S. (1998). Power in Movement: Social Movements, Collective Action and Mass Politics in the Modern Stale. Cambridge: Cambridge University Press, p. 105.

19. Fuchs, Christian (2006). The self-organization of social movements. Systemic Practice and Action Research, 19 (1), pp. 101-137.

20. Luhmann, Niklas (1996). Protest. Systemtheorie und soziale Bewegungen, Suhrkamp, Frankfurt.

21. Бараш, Р. Э., Антоновский, А. Ю. (2018). Коммуникативная философия радикального протеста. Генезис радикализма и позитивная программа его исследований. Вопросы философии, № 9, с. 27-38.

22. Bradley, Anthony, J. (2011). Defining Social Media: Mass Collaboration is Its Unique Value. Gartner, March 08, 2011. URL.: https://blogs.gartner.com/anthony bradley/2011/03/08/defining-social-media-mass-collaboration-is-its-unique-value/? $\mathrm{ga}=2.164595071 .1964803115 .1625839312-155504087.1625839312$

23. Марков, А. А. (1954). Теория алгорифмов, Тр. МИАН СССР. Москва; Ленинград: Изд-во АН СССР, 42, с. 3-375.

24. Chen, Y. and Ying J. (2013). Modeling Community Influence in Social Networks with Markov Chains, International Conference on Cloud Computing and Big Data, Fuzhou, China, pp. 515-520.

25. Rocca, Joseph (2019). Introduction to Markov chains. Definitions, properties and PageRank example. Towards Data Science. URL.: https://towardsdatascience.com/briefintroduction-to-markov-chins-2c8cab9c98ab 
26. Cammaerts, B. Mattoni, A., \& McCurdy, P. (eds.) (2013). Mediation and protest movements, Bristol, UK.

27. Laclau, E., \& Mouffe, C. (1985). Hegemony and Socialist Strategy: Towards a Radical Democratic Politics. London: Verso.

28. Cammaerts, B. (2014). Technologies of self-mediation: Affordances and constraints of social media for protest movements. In J. Uldam \& A. Vestergaard (Eds.). Civic engagement and social media - Political participation beyond the protest, Basingstoke: Palgrave MacMillan.

29. Fedoniuk Sergii (2018). Mass Collaboration as a Factor of the Ukrainian Revolution 2013-2014. Language-Culture-Politics: International Journal, vol. 1, p. 209-218.

30. Федонюк, Сергій (2020). Комунікаційні фактори білоруських протестів, Міжнародні відносини, суспільні комунікації та регіональні студії, № 2 (8), с. 83-99.

\section{COMMUNICATIVE COMPONENT OF MODERN PROTESTS}

This article identifies the features of communication of modern protest movements in aspects of mass cooperation.

It is especially shown that modem social and political protests develop on the basis of mass communication between potential participants who do not rely on formal organizational structures, protest is a self-reproducing process based on the suggestion of alarmism by the media. As a result, social networks, which are able to quickly spread such alarming sentiments among their participants, have begun to play a high role as a driving force behind mass protests. Large mass demonstrations of the last decade were organized by mobilization through social networks, and then showed their strength by the mass presence of people on the street. In turn, protests contribute to the development of social networks with their communities. The main role in this process is played by the communication of protest, which in essence is the communication of open (mass) collaboration. It is formed on the basis of individual information contacts between the subjects who implement them in the environment of social networks. Such communication is interactive and develops through the involvement of information resources from the network. It is characterized by object orientation and the absence of system-structural organization. The second characteristic feature is the convergence of means and participants of communication. What matters more is not the presence of specialized and qualified communicators in the field of traditional media, but the involvement of a large number of information users (professional consumers of information), ie active content generators from among the audience. Communication processes in social networks develop as a series of events in which each subsequent event depends on the previous one. As a rule, such an approach is not able to create a sequence in which there would be a trend and to achieve the planned result requires the formation of foci of influence. In the practice of protest communication, such focusing is carried out through the connection of traditional 
(institutional) media. The result of the interaction of interactive communication and offline is the introduction of a consolidating factor, which should increasingly unite like-minded people against the camp of opponents. These features of protest communication are manifested in the effective interaction of social networks with the traditional media sector.

These properties characterize the protest, which develops on the basis of interactive communication as an open system focused on interaction with the environment and not on internal resources, which is characteristic of mass collaboration.

Key words: communication, protest, social networks.

\section{REFERENCES}

1. Mansour, E (2012). The role of social networking sites (SNSs) in the January 25th revolution in Egypt. Libr. Rev, 61 (2), pp. 128-159.

2. ComScore: ComScore video metrix (2011). URL: http://www.comscore.com/por/. 10 March 2015.

3. Castells, Manuel (2013). Redes de indignagdo e espercmga: movimentos sociaisjicu na era da internet. Tradução Carlos Alberto Medeiros. Rio de Janeiro: Zahar, 271 p.

4. Peruzzo, C. (2013). Movimentos sociais, redes virtuais e midia alternativa no junho em que «o gigante acordou». MATRIZes, 7 (2), pp. 73-93.

5. Harvey, D., Maricato, E., Zizek, S., Davis, M., Maior, J. F, Iasi, M., e de Oliveira, P. R. (2013). Cidades rebeldes: Passe livre e as manifestaçoes que lomaram as ruas do Brasil. Boitempo Editorial.

6. Ramos, A., Oliveira, R. (2014). Indivíduos, sociedade, tecnologia: as manifestaçoes nas ruas das cidades brasileiras e as redes sociais. Revista Tecnologia e Sociedade, 10 (20).

7. Garrett, R. K. (2006). Protest in an information society. Inf. Commun. Soc, 9, pp. 202-224.

8. Webster, J., Watson, R. T. (2002). Analyzing the past to prepare for the future: writing a literature review. MIS Q. 26 (2), pp. xiii-xxiii.

9. Bennett, W. L., \& Segerberg, A. (2013). Tbe logic of connective action: Digital media and the personalization of contentious politics. New York, NY: Cambridge University Press.

10. Castells, M. (2012). Networks of Outrage and Hope, Social Movements in the Internet Age. Polity, Cambridge.

11. Earl, J., \& Kimport, K. (2011). Digitally enabled social change: Activism in the Internet age. Cambridge, MA: MIT Press.

12. Faris, D. (2013). Dissent and Revolution in a Digital Age: Social Media Blogging, and Activism in Egypt. I. B. Tauris, London.

13. Easley, D., Kleinberg J. (2010). Networks, Crowds, and Markets: Reasoning About a Highly Connected World. Cambridge University Press, New York.

14. Newman M. E. J. (2010). Networks. An Introduction. Qxford University Press, Oxford. 
15. Wasserman, S., Faust, K. (1994). Social Network Analysis: Methods and Applications, Cambridge: University Press.

16. Carrington, P. J., Scott, J., Wasserman, S. (2005). Models and Methods in Social Network Analysis. Cambridge University Press, Cambridge.

17. Kadushin, C. (2012). Understanding Social Networks. Theories, Concepts and Findings. Oxford University Press, Oxford.

18. Tarrow, S. (1998). Power in Movement: Social Movements, Collective Action and Mass Politics in the Modern Stale. Cambridge: Cambridge University Press, p. 105.

19. Fuchs, Christian (2006). The self-organization of social movements. Systemic Practice and Action Research, 19 (1), pp. 101-137.

20. Luhmann, Niklas (1996). Protest. Systemtheorie und soziale Bewegungen, Suhrkamp, Frankfurt.

21. Бараш, Р. Э., Антоновский, А. Ю. (2018). Коммуникативная философия радикального протеста. Генезис радикализма и позитивная программа его исследований. Вопросы философии, № 9, с. 27-38.

22. Bradley, Anthony, J. (2011). Defining Social Media: Mass Collaboration is Its Unique Value. Gartner, March 08. URL: https://blogs.gartner.com/anthony_bradley/2011/03/08/defining-social-media-mass-collaboration-is-its-unique-value/? $\mathrm{ga}=2.164595071 .1964803115 .1625839312-155504087.1625839312$

23. Марков, А. А. (1954). Теория алгорифмов, Тр. МИАН СССР. Москва; Ленинград: Изд-во АН СССР, 42, с. 3-375.

24. Chen, Y. and Ying J. (2013). Modeling Community Influence in Social Networks with Markov Chains, International Conference on Cloud Computing and Big Data, Fuzhou, China, pp. 515-520.

25. Rocca, Joseph (2019). Introduction to Markov chains. Definitions, properties and PageRank example. Towards Data Science. URL.: https://towardsdatascience.com/briefintroduction-to-markov-chins-2c8cab9c98ab

26. Cammaerts, B. Mattoni, A., \& McCurdy, P. (eds.) (2013). Mediation and protest movements, Bristol, UK.

27. Laclau, E., \& Mouffe, C. (1985). Hegemony and Socialist Strategy: Towards a Radical Democratic Politics. London: Verso.

28. Cammaerts, B. (2014). Technologies of self-mediation: Affordances and constraints of social media for protest movements. In J. Uldam \& A. Vestergaard (Eds.). Civic engagement and social media - Political participation beyond the protest, Basingstoke: Palgrave MacMillan.

29. Fedoniuk Sergii (2018). Mass Collaboration as a Factor of the Ukrainian Revolution 2013-2014. Language-Culture-Politics: International Journal, vol. 1, p. 209-218.

30. Федонюк, Сергій (2020). Комунікаційні фактори білоруських протестів, Міжнародні відносини, суспільні комунікації та регіональні студії, № 2 (8), с. 83-99.

Матеріал надійшов до редакиії 05.01.2021 p. 
УДК 811.111'373.612.2’22

\section{Галина Харкевич,}

кандидат філологічних наук, доцент кафедри іноземних мов та перекладу, Волинський національний університет імені Лесі Українки,

ORCID ID 0000-0001-6681-5251

Kharkevych.Halyna@vnu.edu.ua

DOI 10.29038/2524-2679-2021-01-188-195

\section{СЕМІОТИЧНІ АСПЕКТИ ПЕРЕКЛАДОЗНАВСТВА (НА МАТЕРІАЛІ АНГЛІЙСЬКОЇ МОВИ)}

У статті розглянуто особливості перекладу метафор крізь призму семіотичного підходу. У роботі уточнено лінгвосемантичну типологію знаків (ікона - індекс-символ). Під індексами в семіотиці розуміють знаки, щзо виконують функиію вказівки чи впливу на деякий об' єкт. Іконічний знак трунтується на фактичній подібності означаючого й означуваного. Символ передбачає використання свого первинного змісту в якості форми іншого, як правило, культурно иіннішого змісту. Кожний знак має три види зв'язків, без яких він не може виконувати своєї функиії. Знак пов'язаний із тим, що він позначає, що в семіотиці називається семантикою знака. Існуючи в системі, знак пов'язаний з іншими знаками иієї системи. Знак пов'язаний із людьми, які використовують його, оскільки він може бути знаком лише для когось.

Проаналізовано деякі труднощі перекладу англомовних метафор. Існують мовні та мовленнєві метафори. Перекладні відповідники перших зафіксовані в перекладних словниках. Мовленнєва метафора не має усталених перекладних відповідників $і$ виступає семантичним новоутворенням. Існують три основні способи передачі метафоричних слів: метафоричним словом, яке має подібний характер образності; метафоричним словом, що має інший характер; неметафоричним словом, що передає лише денотативний зміст метафоричного слова.

У статті охарактеризовано конвенційні й неконвенційні символи. У словниках та енциклопедіях символів містяться конвенційні символи. Різновидом конвенщійних символів є жести, що є культурно обумовленими та мають договірний характер. Неконвенційний символ виникає в результаті творчого акту автора, являючи собою символізований троп, що поєднує концептуальний та вербальний аспекти знака.

Ключові слова: семіотика, знак, метафора, символ, жест, перекладні відповідники.

(C) Харкевич Г., 2021 